\title{
Capitalizing Asian STUdies: Critical Scholarship and the Production of Knowledge in a Globalizing World
}

\author{
Tim Oakes \\ University of Colorado at Boulder
}

\section{Producing Knowledge in an Era of Globalization: Two Examples}

I want to begin with two examples from the United States of 'capitalizing' Asian Studies. The first example is a project called 'Asia in the Schools.' Funded by the Freeman Foundation and coordinated by the New York-based Asia Society, Asia in the Schools is a laudable push toward better K-12 education about Asia in the US. A tour of the project's web site in 2001 suggested that the issue driving its mission of 'preparing young Americans for the demands of a complex global order in which Asia looms large' seems to be this: is America ready for the challenge of the Asia market? ${ }^{1}$ Or, we may have won the Cold War, but are we prepared to win the 'Pacific Century?' Or, is American capitalism prepared to meet the demands of a robust, WTO sanctioned China market? Thus, the project's initial web site tracked Asia-related curricula in each US state, correlated with state-level data on trade with Asia - presumably as a way of evaluating whether states were matching their Asian market capacity with adequate education about Asia. Now, I don't want to pick on this project: I think it's an excellent project, and I think we're lucky to have the Freeman Foundation around to fund it. I do want to recognize, however, that the production of knowledge is never neutral, and that Asia in the Schools seeks to produce knowledge within a broader context in which US economic interests in Asia make certain kinds of knowledge about Asia valuable.

The second example of 'capitalizing' Asian Studies is rather more literal than the first: in the 1990s, the US Association for Asian Studies (AAS) had accumulated a significant portfolio in stock holdings, much of which was international. In 1999 alone the AAS

\footnotetext{
${ }^{1}$ In 2001, Asia in the Schools could be found at http://www.asiaintheschools.org/. The current site is http://www.internationaled.org/. A complete report on the initiative can be found at http://www.internationaled.org/report.htm. See also http://www.askasia.org/.
} 
investment portfolio grew by some $\$ 857,000$ (Duus 2000 , pp. 6-7). This raises some particularly bothersome questions for some of the AAS membership. During the Asian financial crisis, when Indonesia's economy (and a good many of its poorer citizens) lay dying from the 'drive-by shooting' of derivatives speculators, causing overnight an $86 \%$ drop in the value of its stock market, US stock values increased by $31 \%$ (Kristof \& Wyatt 1999). ${ }^{2}$ So US Asianists might feel rather uncomfortable about the possibility that some of the remarkable success that their organization's holdings have enjoyed have not been so innocently realized. According to a recent letter by AAS president Peter Duus, the association maintains a 'socially conscious' approach to its investments on a case-by-case basis, but socially conscious investing is clearly secondary to assuring the 'maximum long term performance of the AAS investment portfolio' (Duus 2000). It is probably worth mentioning, too, that in this same letter, Duus quotes Deng Xiaoping's rhetorical remonstration to his fellow countrymen to throw off their shackles of egalitarianism. 'To get rich is glorious,' Deng and Duus tell us. Now, if the Association's pursuit of wealth must be legitimized by a man who oversaw China's transformation over the past 20 years into one of the world's most unequal societies - not to mention his army's massacre of anti-corruption protesters in 1989- this is indeed troubling. But I don't mean to pick on the AAS either. The concept of 'socially conscious' investing is, after all, highly suspect, and may be nothing more than a panacea for our collective liberal guilt. But the issue points to a larger concern that I want to explore in this paper: Not only is knowledge production never neutral, but it is intimately tied up with broader political economic processes in often very mundane ways.

In some respects, these are two examples of what Appadurai has called 'anxieties of the global': the first case suggests an anxiety over meeting the challenge of globalization, while the other is a moral anxiety over the ethics of globalization. 'Everyone in the academy,' Appadurai observes, 'is anxious to avoid seeming to be a mere publicist of the gigantic machineries that celebrate globalization' (2000, p.1). And yet, we strive to make our knowledgeable voices heard among the hum of global media churning out ticker-tape

\footnotetext{
${ }^{2}$ This is not to insist on a direct correlation between US stock portfolio increases and Asia's market demise, but rather to illustrate how the booms and busts of world markets are regional rather than global.
} 
parades of information; we strive to meet the challenge of globalization just as we distance ourselves from it.

These anxieties arise as the result of a broader set of changes both in the global political economy, and in the nature of area studies scholarship. My goal here is to discuss these changes in parallel in order to clarify the relationship between the two. I'll start with the shift in the nature of area studies, as demonstrated by shifting funding priorities. This shift, I will argue below, mirrors a larger shift in global political economy, in which the scales at which geographical knowledge is produced are increasingly in flux. Scholarship is subsequently left scrambling to both understand this shift and make its knowledge production somehow relevant and valuable in an arena in which knowledge about Asia is being produced and diffused from an increasingly diverse array of sources, in which area studies scholars are perhaps increasingly marginalized.

\section{The Shift in Area Studies}

By now most area studies scholars have come to realize that the terrain of our field has been shifting away from producing knowledge about areas as coherent and bounded units, to a focus on processes that increasingly link areas together. Notwithstanding the Bush administration's efforts to re-imagine the world as fundamentally divided along the age-old fault-lines of religion and morality, funding imperatives for area studies have shifted from cold war geopolitics to concerns over trade relations, globalization, developing markets and market institutions in post-socialist states. ${ }^{3}$ Within the American AAS, this shift has been recognized for some time, as evidenced, for example, by a presidential panel in 1997 on the 'Futures of Asian Studies.' (http://www.aasianst.org/Viewpoints/futures.htm). Other institutions have recognized it as well. For example, the 'Regional Worlds' project at the University of Chicago seeks to replace what Appadurai refers to as 'trait' geographies with 'process' geographies, thereby infusing area studies with the global processes that link world regions together, generating imaginative new 'pictures of the world'

\footnotetext{
${ }^{3}$ While the September 11, 2001 attacks on the US resulted in a brief revival of official calls to continue developing "area specialists" in the Middle East, the so-called "war on terrorism" has yet to mark a reversal of the shift in area studies towards globalization and integration. For a related discussion, see Wang (2002).
} 
(http://www.regionalworlds.uchicago.edu). Similarly, the Ford Foundation has made a now well-known shift away from areas per se and toward innovative boundary-crossing work, sponsoring, for example, special 'boundary-crossing' panels at annual AAS meetings. And the focus of the Social Science Research Council (SSRC) is now 'to understand how the culture, history, and language of a local context shape its interaction with, for example, the evolution of market institutions and engagement with international market forces' (Heginbotham 1994, p. 37). As the SSRC sees it, scholarship should be 'context-sensitive,' and thus not committed to traditionally received 'areas' or countries. Thus, sub-national regions, and supranational regions are now important too, as are perspectives in which 'global-local processes' come into focus (Abraham and Kassimir 1997). 'The geographic scope of area studies programs will need to be broader and more highly diversified than in the past. Contexts will be defined less exclusively by political/military/security criteria and more by a mix that includes economic, trade, cultural, legal, educational, and communications criteria' (Heginbotham 1994, pp. 37-38). It is increasingly recognized that 'areas' are highly differentiated, requiring greater sensitivity to local context.

This shift has not occurred without a great deal of reflexive concern among area studies scholars. There was some concern expressed at a joint meeting between the SSRC and the American Council of Learned Societies (ACLS) in April 1997 over whether the international program in area studies funding was reinforcing an 'ideology of globalization,' in which history was being marginalized (Abraham and Kassimir 1997, p. 28). This concern can also be read as one over the increasing interest in and concern over the production of geographical knowledge. Thus, an unstated theme underlying the shift in area studies has been the uncritical enshrining of a new set of geographical categories for knowledge production: spatial interaction, diffusion, transnationalism, global-local, region, locality, and the like.

Cumings (1997) has argued that the new geography of area studies is marked by a striking (and surprising) lack of political economy in general, and attention to 'the global corporation' in particular. Such a lack represents an unwillingness or an inability to 
reflect on what he finds most troubling in the relationship between area studies scholarship and national political and economic interests: 'To put a subtle relationship all too crudely, power and money have found their subject first, and shaped fields of inquiry accordingly' (1997, p. 9). It is now clear that cold war security concerns not only provided the major policy and funding push for the development of area studies following World War II, but also seriously compromised the scholarly integrity of many area studies programs in the US through their direct links to national security institutions such as the OSS, CIA and the FBI. What is generally less clear, however, is that the current shift in area studies scholarship mirrors a related shift in the broader political economy of the world system and the changing situation of the United States within that system. Today we may look back on cold war area studies scholarship and lament from a safe historical distance the blatant compromises of academic freedom that often occurred. We perhaps lack a similar reflexivity, however, regarding the broader political economic conditions for the contemporary construction of area studies knowledge, a point noted by Cumings: 'Perhaps the most disappointing aspect of the new SSRC/ACLS restructuring and the apparent new direction of the major foundations is the absence of any reference to the basic motivation for so many of the new tendencies in the 1990s world that they hope to adapt themselves to, namely, the global corporation' (1997, p. 26). Area Studies, according to Cumings, should remain focused on political economy to redress this disappointment.

\section{The Commodification of Knowledge}

Thorough and bracing as Cumings's critique is, it falls short of interrogating the political economic processes that shape geographical knowledge at the beginning of the $21^{\text {st }}$ century. These processes are part of what Rafael calls a distinctly 'North American style of knowing,' one that is 'fundamentally dependent on, precisely to the extent that it is critical of, the conjunction of corporate funding, state support, and the flexible managerial systems of university governance characteristic of liberal pluralism' (Rafael 1994, p. 41).

What is happening in area studies is reflected at the larger scale of the North American university itself. That is, a general trend toward the corporatization of the university and 
the commodification of higher education (Mitchell 1999; Robins 2000). Readings describes the trend thus: 'the University is becoming a transnational bureaucratic corporation, either tied to transnational instances of government such as the European Union or functioning independently, by analogy, with a transnational corporation' (1996, p. 3). This trend has been succinctly captured in such brave-new-world terminology as 'digital diploma mills,' the 'knowledge universe' (convicted junk-bond trader Michael Milken's new business venture), the 'virtual university,' and some of the more tongue-incheek versions: 'McCollege' and the 'APM' or 'Automatic Professor Machine' (Noble 1997). Facing state-mandated budget cuts, universities increasingly turn to corporate partnerships, many of which are not fully disclosed and thus raise serious questions about academic freedom and the ownership of intellectual property (Mitchell 2001). Not surprisingly, the transformation of education in the digital age has become the policy objective of state governments throughout the US. In Washington State, Governor Gary Locke formed a panel in 1998, called the 2020 Commission, to consider the future of education in the state (Mitchell 1999). The panel included '21 of the state's best and brightest community leaders,' not one of which was a university teacher. Rather the panel included CEOs of Weyerhaueser Company, Costco, and many other corporate interests. The panel advocated a shift in thinking about higher education, in which digital distance learning would streamline bloated university budgets and staff, where universities would be held accountable for their 'output' and where students would become 'customers' in a competitive education marketplace.

This system of 'flexible education' mirrors a broader political economy of 'flexible specialization' in late capitalism. Indeed, Robins (2000) has argued that the virtual university represents less a technological change in education than a changing political economy of education associated with the forces of globalization. Robins sees universities increasingly serving the function of providing skilled workers for the needs of transnational capital. This perspective has been echoed by Readings (1996), who has argued that the university as we know it is a defunct institution that was created to serve the national interests of the $19^{\text {th }}$ century state. This 'cultural university' of the $19^{\text {th }}$ and $20^{\text {th }}$ centuries is being replaced by the 'technological university,' the 'corporate 
university,' and the 'University of Excellence' of the $21^{\text {st }}$ century, in which national knowledge is replaced with 'dereferentialized knowledge.' Readings calls it nothing short of 'rethinking the categories that have governed intellectual life for over two hundred years' (p. 169). Nor is this a call for a more multicultural or cultural studies-oriented curriculum, for these too often serve to merely legitimize the corporate commodification of knowledge, emphasizing hybridity and transnationalism in ways that strikingly parallel the vision statements of companies like Microsoft, Nike, and Coca-Cola (Dirlik 1994; Mitchell 1997). For Readings, Cultural studies 'presents a vision of culture that is appropriate for the age of excellence (Readings 1996, p. 11; see a similar critique in Wang 2002).

It should not be surprising, then, that even Area Studies institutions like the AAS maintain a substantial stock portfolio. Scholarly institutions need to be players if they are to survive. But the question is not whether the AAS, or universities, should or should not be in the business of international investing. Rather, the question is how do we situate our scholarship in a world where the political economy of knowledge production is undergoing immense transformation. It is this question of political economy, raised earlier by Cumings, that lies at the core of my argument here. For all the anxiety over the shifts in area studies funding priorities, the futures of the AAS and so on, there remains very little sustained analytical interrogation of the role of capital in shaping the knowledge universes that we inhabit.

\section{Scaling Geographical Knowledge}

In addressing this question, I want to focus on the production of geographical knowledge, for if the shift in area studies mirrors a transformation in the global political economy where the scales at which geographical knowledge is produced have themselves shifted, then even non-area related disciplinary approaches in humanities and even social sciences are themselves being spatialized. Ever since Foucault (1996, p. 22) proposed that we now live 'in the epoch of space,' 'mapping' has become the metaphor of the times in 'cutting-

edge' scholarship. The increasing interest in global-local relationships, in traditional areas differentiated into more context-specific regions and localities, in a borderless world, in 
globalization, in the progressive potential of the Internet, World Wide Web, and multiculturalism - all of these derive in part from capital's own need to produced new spatial scales of accumulation and, thus, associated scales for the production of geographical knowledge (Brenner 1997; Cartier 2001; Harvey 1995). Shifting scales of knowledge represent capital's incessant efforts to abstract from the actual social conditions of production, such that they become mystified into absolute categories of culture, ethnicity, locality, nation, or region (Comaroff \& Comaroff 2000).

Geographers in particular have been engaged in a sustained critique of what has been called capital's 'production of scale,' and this work offers a basis from which to critically interrogate the production of knowledge in today's area studies fields (Smith 1986, pp. 57-78). Of course, a critique of capital's production of scale is simply part of the more general theoretical argument, 'that scale is neither an ontological given and a priori definable geographical territory nor a political neutral discursive strategy in the construction of narratives' (Swyngedouw 1997, p. 140). This is because different processes produce different scales of activity and meaning. Scales of processes that we find important (the local, the global, the regional, whatever) 'are the result, the product of processes, of sociospatial change' that is 'always heterogeneous, conflictual, and contested. Scale becomes the arena and moment, both discursively and materially, where sociospatial power relations are contested and compromises are negotiated and regulated. Scale, therefore, is both the result and the outcome of social struggle for power and control' (p. 140). Events such as the 1997 collapse of the baht in Thailand are the result of innumerable scaled processes coming together at a particular location and time. We should be thinking of these scaled processes and how they come together in space and time to affect disruptive change. Rather than merely injecting the political economy of the global corporation into our scholarship of spatial processes, then, a critical area studies needs to be focusing on how, and in whose interests, scales of knowledge are being produced and contested.

To put it another way, the production of scale raises two important issues of concern to area studies fields. Most obvious is that Appadurai's 'process' geographies make a lot of 
sense, affording a new look at the 'regional worlds' in which different geographical understandings are formulated as people encounter the increased flows and disjunctures of the global economy. Rather than reifying areas and regions, we should be focusing on 'the struggles between individuals and social groups through whose actions scales and their nested articulations become produced as temporary standoffs in a perpetual transformation of sociospatial power struggle' (Swyngedouw 1997, p. 141). The other issue raised by the production of scale is that despite the sense that 'process' geographies make, it is perhaps more important to realize that scaled processes occur at all scales, that they are unruly, but that they are more often than not dominated by power whereby particular scales emerge to displace others. The regional, it turns out, tends to be one of those scales dominated by power. Thus, the 'process' of capital, Wilson and Dirlik (1995, p. 6) observe, has been actively producing the scale of the 'Pacific Rim' as a 'coherent region of economic exchange,' and thereby actively repressing those scales of knowledge produced by less hegemonic interests: those of inter-island cultural and social interaction and differentiation. (see also Cumings 1993). This is something about which Appadurai seems to have much less to say, and which brings us to Harvey's recent observations regarding the production of geographical knowledge and our role as critical academics.

Geographical knowledge, Harvey observes, is very difficult to pin down in theoretical terms. Perhaps this explains some of the defensiveness of the area studies tradition with regard to theory: 'Geography is an empirical form of knowledge that is marked as much by contingency and particularity as by the universality that can be derived from first principles' (Harvey 2000, pp. 534-35; see also Ong 1999, pp.10-11). This contingent and particularistic quality of geographical knowledge can be disturbing to other forms of rational understanding, such that 'the insertion of space (let alone of tangible geographies) into any social theory ... is always deeply disruptive of its central propositions and derivations ... This disruptive effect makes space the favored metaphor in the postmodernist attack... upon all forms of universality' (Harvey 2000 p. 539). From the view of philosophy, this is profoundly ironic, because it was space, after all, that was enshrined by Kant as the ultimate category of universalist thinking in the first place (Casey 1997). But in fact geography is fragmented, synthetic, unruly and subject to 
appropriation by any and all; it is a form of knowledge difficult to contain. This is why the line is often blurred between geography as a source of resistance to power-for example in the turn to local knowledge and diversity in the face of the homogenizing forces of globalized mass production - and geography as a source of legitimacy for all forms of bigotry and the exclusionary politics. This latter use of geography can be seen in the turn to locality as an exclusive enclave where outsiders aren't welcome, as in the rise of local nationalisms, anti-immigrant politics, and conservative legislation that attempts to banish the 'outsiders' among us: gays, lesbians, the homeless.

The unruly production and appropriation of scaled geographical knowledge is perhaps most clearly illustrated these days on the World Wide Web, where all kinds of geographical knowledge are being produced and disseminated instantaneously. The Web illustrates well the blurry lines between geographies of power, appropriation, and resistance. But despite the free-wheeling and chaotic nature of the internet, where a seemingly infinite number of spaces for the production of knowledge pop up - to use a Chinese metaphor-like mushrooms after a spring rain, the production and dissemination of geographical knowledge on the web remains dominated by powerful commercial and communications interests who write a regional world in very selective ways.

How, for example, is the geography of China being written on the English-language Web these days? Since the mid-1990s, dozens of major English language web sites devoted to disseminating information about China as a new region on the frontiers of global capitalism have sprung up. One is Inside China Today (ICT), run by the European Internet Network (EIN) which was founded in 1995 to update global professionals on current events and business opportunities in post-socialist Central Europe (http://www.einnews.com/china/). Now covering some 240 countries (at last count) EIN aims its sites at the world's business elite, those seeking opportunities in the emerging markets of post-socialist states and other world regions. In the month of October, 2000, EIN sites received some 6 million page views from 350,000 'unique users,' $68 \%$ of whom lived in North America, $75 \%$ of whom were male, nearly half of them earning over $\$ 50,000$. ICT - 'a service for global professionals' - features news, with an emphasis on business news, but also offers 'country info,' 'discussion chat,' 'dating,' and an extensive 
online shopping department. Like other sites constructing a comprehensive regional geography aimed at the global investor, ICT represents itself not simply as a provider of information, but as an online 'China community' that inhabits the virtual space of the region it seeks to construct.

ICT gets plenty of competition from China Online, based in Chicago (http://www.chinaonline.com/default.asp). China Online offers much the same businessoriented approach to China as $I C T$, but also claims to offer its information faster than other providers. China Online also used to feature an 'entertainment and lifestyle' site called China Pop, 'providing fresh, unique, wholesome programming to the Chinesespeaking world and sponsorship opportunities to companies seeking to increase their brand building and business prospects in China.' While this cultural side of the business has apparently been dropped, China Online still 'offers media companies high-quality content, which in turn helps them to expand viewership and increase advertising revenues.' Like ICT, China Online is a subscription-based service and, also like ICT, counts among its subscribers many universities and educational institutions around the world.

The point here is not that business-oriented web sites should not be in the business of producing geographical knowledge. Rather, it is that 'China' has become an overdetermined geographical category, a 'scale' representing the convergence of capital interests. As a region, China is being produced for global consumption in many different ways, but particularly in ways that are dominated by the interests of capital. Scholarship that examines China in terms of 'process' geographies must first and foremost acknowledge how dominant interest are at work in producing the scale at which China becomes recognizable in the first place.

\section{Producing Regionalism}

These ideas offer a critical interrogation of the shift in area studies broached at the beginning of this paper. They suggest that the shift itself is part of broader shift in the political economy of capitalism. They also suggest that the issue is not whether this shift 
is a good or bad thing. Rather, the issue is our recognition that we are engaged in a field of geographical knowledge production in which there are many powerful agents contributing to the restructuring of the scales in which that knowledge is expressed. As area scholars we are not ourselves particularly powerful actors in this restructuring; but that doesn't mean we simply accept spatial restructuring as a given. Nor does it mean that we must become willing contributors to dominant agents of the restructuring of geographical knowledge. In this final section I want to explore further the ways regional scales of knowledge - particularly those constructing regional cultural categories - are being restructured as part of the dynamic political economic processes transforming Asia and its relation to the global economy. I focus on the region because a restructured regionalism seems to be the most obvious outcome of the shifts in area studies scholarship described above.

Despite the fact that the rhetoric of globalization often assumes that the global and local scales are the only ones that matter anymore, empirical analysis reveals that state territorial regulation and planning still influences the geography of global capital a great deal. ${ }^{4}$ Indeed, 'competitive advantage' in the global economy often depends on regionally-specific factors that are created or encouraged by state practice (Dicken 1998). For states, benefiting from globalization may thus entail a careful balancing between cultivating place-specific development advantages while at the same time conforming to global standards of deregulation in local labor and financial markets. One region-specific factor that states often seek to cultivate as a development advantage which does not threaten the uniform standards sought by investors is distinctive regional culture (Kearns \& Philo 1993; Lash \& Urry 1994; Zukin 1995; Dirlik 1996; Peet 1997). One of the ways that territoriality remains important in a globalizing world, then, is in its demarcation of a culture region that is somehow attractive to deterritorialized capital. Such attractiveness may be expressed in many ways: a culture of skilled and hardworking laborers, a culture of entrepreneurialism, or a culture of 'traditional' values and beliefs conducive to modernization. It is often the state's role to actively represent regional culture in these

\footnotetext{
${ }^{4}$ For celebrations of the demise of regional boundaries, see Castells (1989) and Ohmae (1990). For the counterargument, see Cox (1997) and Storper (1997).
} 
terms, while seeking to erase any negative cultural images that may commonly be held about the region (Morley \& Robins 1995).

The increasing interest among business elites in the importance of regional culture reflects common assumptions held in explaining the successful 'tigers' and 'dragons' of the 'Asian economic miracle' (Gertler 1997). Here, cultural factors are said to facilitate the needs of advanced, 'flexible' capitalism: inter-firm cooperation and collaboration, vertical disintegration in large firms, and diverse forms of outsourcing (Harrison 1992; Leung 1993). Production, in other words, is seen as more dependent on social relations than in the past, suggesting an advantage for regions with the appropriate 'traits,' such as strong cultural bonds of kinship, ethnicity, language, and/or religion (Kotkin 1993). A well-established literature on 'Chinese capitalism' tends to situate the success of overseas Chinese business within a discourse of time-honored 'Confucian values' and 'Chineseness.' (Chan \& Chiang 1994; Weidenbaum \& Hughes 1996). Thus, explanations of Chinese business networks have emphasized the kinship and native-place based practice of guanxi, or 'connections' (Redding 1990; Yang 1994).

As Ong (1999, p. 68) notes of these kinds of 'trait' geographies, 'Chinese race, culture, and economic activities have become naturalized as inseparable or even the same phenomena.' (see also Berger 1996). It is the production of the regional scale that enables such cultural coherencies to emerge. Olds and Yeung (1999, p. 541) have also criticized much of this work for explaining regional Chinese business networks according to 'internalized factors associated with culture and identity' expressed at regional scales. In fact, the scale of 'Chinese capitalism' as a regional phenomenon is highly contested and shifting. Olds and Yeung argue that ethnic Chinese business networks are increasingly disrupted by external forces of global capital, compelling them to adopt more 'credible' and 'transparent' management practices as defined by global financial gatekeepersthose who perhaps also bookmark Inside China Today or China Online on their web browsers. What these critiques point to is the role of ideology among state and business elites. Although Asian states must, in essence, 'play by the rules or be left behind,' they actively promote a rhetoric of cultural difference vis-à-vis the west, that adds a dynamic 
dimension to their competitiveness. Maintaining an ideology of regional culture serves to distinguish a territorial region, increasing its visibility in the pathways of capital, while allowing conformity with the norms of the deregulated global economy.

Ching also sees such regionalist projects as ideological formations. He adds that,

conceiving regionalism as a discursive construct instead of an empirical reality serves better to explain the differing constructions of regionalist projects within late capitalism. Political and economic rationalism alone cannot explain why Asian regionalism has been, more often than not, articulated on cultural grounds rather than on grounds that are economic (as in North America) or political (as in Western Europe) (2000, p. 239).

The answer is not simply that the regionalist discourse of 'Asian values' or 'Chinese capitalism' depends on an ideology of culturalism, but that such ideologies are mobilized as politics of scale, in which state interests converge with and negotiate those of international capital.

This leaves us with a need to recognize that the shifting categories by which our knowledge is produced, disseminated, and received, are not innocent. Certainly they cannot be celebrated as 'innovative' or 'cutting-edge,' as if capital had never heard of transnationalism or hybridity until scholars started tossing these ideas around. We need to be aware of the broader context for the shift in area studies and that 'crossing borders' (disciplinary, international, social, or mental) does not necessarily mean much more than just keeping up with the times. If, however, we wish to do more than 'keep up with the times,' then a critical focus on the production of scale seems a good place to start.

\section{Reference List}

Abraham, I. \& Kassimir, R. 1997, 'Internationalization of the social sciences and humanities', Items vol. 51 no. 2-3, pp. 23-30.

Appadurai, A. 2000, 'Grassroots globalization and the research imagination', Public Culture, vol. 12 no. 1, pp. 1-19.

Berger, M. 1996, 'Yellow mythologies: the East Asian miracle and post-cold war capitalism', positions: east asia cultures critique, vol. 4 no. 1, pp. 90-126.

Brenner, N. 1997, 'Global, fragmented, hierarchical: Henri Lefebvre's geographies of globalization', Public Culture, vol. 10 no. 1, pp. 135-167.

Cartier, C. 2001, Globalizing South China, Oxford, Blackwell. 
Casey, E. 1997, The Fate of Place: A Philosophical History, Berkeley CA, University of California Press.

Castells, M. 1989, The Informational City: Information Technology, Economic Restructuring, and the Urban-Regional Process, Oxford, Blackwell.

Chan, K.B. \& C. Chiang. 1994, Stepping Out: The Making of Chinese Entrepreneurs, New York, Simon and Schuster.

Ching, L. 2000, 'Globalizing the regional, regionalizing the global: mass culture and Asianism in the age of late capital', Public Culture vol. 12 no. 1, pp. 233-257.

Comaroff, J. \& Comaroff J.L., 2000, 'Millenial capitalism: first thoughts on a second coming', Public Culture vol. 12 no. 2, pp. 291-343.

Cox, K. (ed.) 1997, Spaces of Globalization: Reasserting the Power of the Local, New York and London, Guilford.

Cumings, B. 1993, 'Rimspeak', in What Is In a Rim? Critical Perspectives on the Pacific Region Idea, eds. A. Dirlik \& R. Wilson, Boulder, CO, Westview, pp. 29-47.

1997, 'Boundary displacement: area studies and international studies during and after the cold war', Bulletin of Concerned Asian Scholars vol. 29 no. 1, pp. 6-26.

Dicken, P. 1998, Global Shift: Transforming the World Economy, $3^{\text {rd }}$ edn, New York and London, Guilford.

Dirlik, A. 1994, After the Revolution: Waking to Global Capitalism, Hanover, Wesleyan University Press.

1996, 'The global in the local', in Global / Local: Cultural Production and the Transnational Imaginary, eds R. Wilson \& W. Dissanayake, Durham, NC, Duke University Press, pp. 21-45.

Dirlik, A. \& Wilson, R. (eds) 1995, Asia/Pacific as Space of Cultural Production, Durham, NC, Duke University Press.

Duus, P. 2000, 'On riches, virtue and the great bull market', Asian Studies Newsletter, vol. 45 no. 2 , pp. 6-7.

Foucault, M. 1986, 'Of other spaces', trans. J. Miskowiec, Diacritics, vol. 16 no. 1 (spring).

Gertler, M. 1997, 'The invention of regional culture', in Geographies of Economies, eds R. Lee \& J. Wills, London, Arnold pp. 47-58.

Hamilton, G.G. 1991, Business Networks and Economic Development in East and South East Asia, Hong Kong, University of Hong Kong Center for Asian Studies.

Harrison, B. 1992, 'Industrial districts: old wine in new bottles?' Regional Studies 26, pp. 469-893.

Harvey, D. 1995, 'Militant particularism and global ambition: the conceptual politics of place, space, and environment in the work of Raymond Williams', Social Text 42, 69-98.

2000, 'Cosmopolitanism and the banality of geographical evils', Public Culture, vol 12 no. 2, pp. 529-564.

Heginbotham, S. 1994, 'Rethinking international scholarship', Items vol. 48 no 2-3, pp. 33-40.

Kearns, G. \& C. Philo, C. (eds) 1993, Selling Places: The City as Cultural Capital, Oxford, Pergamon.

Kotkin, J. 1993, Tribes: How Race, Religion, and Identity Determine Success in the New Global Economy, New York, Random House. 
Kristof, N. \& Wyatt, E. 1999, 'Who went under in the world's sea of cash?', New York Times, 15 February, A1.

Lash, S. \& Urry, J., 1994, Economies of Signs and Spaces, London, Sage.

Leatherman, C. 2001, 'Tourism scholar says U. of Montana violated her academic freedom', The Chronicle of Higher Education, 19 February. Available: http://chronicle.com/daily/2001/02/2001021904n.htm

Leung, C.K. 1993, 'Personal Contacts, Subcontracting Linkages, and Development in the Hong Kong - Zhujiang Delta Region', Annals of the Association of American Geographers vol. 83 no. 2, pp. 272-302.

Mitchell, K. 1997, 'Different diasporas and the hype of hybridity', Environment and Planning D: Society and Space, vol. 15 no. 5, pp. 533-553. 1999, 'Commentary', Environment and Planning, vol. 31 no. 3, pp. 381-388.

Morley, D. \& Robins K., 1995, Spaces of Identity: Global Media, Electronic Landscapes, and Cultural Boundaries, London and New York, Routledge.

Noble, D. 1997, 'Digital diploma mills, part I: the automation of higher education', First Monday [Online]. Available: http://firstmonday.dk/issues/issue3_1/noble

Ohmae, K. 1990, The Borderless World: Power and Strategy in the Interlinked World Economy, New York, Harper Business.

Olds, K. \& Yeung, H.W.C. 1999, '(Re)shaping "Chinese” business networks in a globalising era', Environment and Planning D: Society and Space vol. 17 no. 5, pp. 535-555.

Ong, A. 1999, Flexible Citizenship: The Cultural Logics of Transnationality, Durham, NC, Duke University Press.

Peet, R. 1997, 'The cultural production of economic forms', in Geographies of Economies, eds R. Lee and J. Wills, London, Arnold, pp. 37-46.

Rafael, V. 1994, 'The cultures of area studies in the United States', Social Text 41, pp. 91-111.

Readings, B. 1996, The University in Ruins, Cambridge, MA, Harvard University Press.

Redding, S.G. 1990, The Spirit of Chinese Capitalism, Berlin, W. de Gruyter.

Robins, K. 2000, The virtual university. Talk given at the University of Colorado Spring Colloquium Series, Boulder, CO, April.

Smith, N. 1986, 'Geography, difference, and the politics of scale', In Postmodernism and the Social Sciences, eds J. Doherty, E. Graham, and M. Malek, New York, St. Martin's Press, pp. 57-78.

Storper, M. 1997, The Regional World: Territorial Development in a Global Economy, New York and London, Guilford.

Swyngedouw, E. 1997, 'Neither global nor local: "glocalization" and the politics of scale', in Spaces of Globalization: Reasserting the Power of the Local, ed. K.R. Cox, New York and London: Guilford, pp. 137-166.

Viewpoints (July, 1997): The futures of Asian studies [Online], 1997. Available: http://www.aasianst.org/Viewpoints/futures.htm

Wang, B. 2002, 'The cold war, imperial aesthetics, and area studies', Social Text 20 (3): pp. 45-65.

Weidenbaum, M. \& S. Hughes, 1996, The Bamboo Network: How Expatriate Chinese Entrepreneurs are Creating a New Economic Superpower in Asia, New York, Free Press. 
Yang, M. 1994, Gifts, Favors, and Banquets: The Art of Social Relationships in China, Ithaca, NY, Cornell University Press.

Zukin, S. 1995, The Cultures of Cities, Oxford, Blackwell. 